\title{
Principal Managerial Competencies in the Implementation of Inclusive Education
}

\author{
Firlia Rahmi*, Murniati, Nasir Usman \\ Master of Education Administration \\ Syiah Kuala University \\ Banda Aceh, Indonesia \\ *firliarahmi@gmail.com
}

\begin{abstract}
This study is aimed at determining the principals' managerial competence in implementing inclusive education. The principal's managerial competence is the ability to manage all the resources and potentials contained in the school effectively and efficiently. The results showed that the planning carried out by the schools providing inclusive education in Banda Aceh had not been well documented, and only some schools had put it into the vision, mission and goals of the school. The positive thing that was found in the schools that provided inclusive education was the very high commitment of each school principal in implementing inclusive education. They are able to build the sensitivity of all teachers in handling students with special needs optimally. The principal together with teachers and parents of students are able to establish good communication in dealing with students with special needs. The inhibiting factor faced by schools is that special guidance teachers (GPK) provided by the schools, have not sufficient with the number of students with special needs. The available infrastructure has not been fulfilled in accordance with the needs of students with special needs.
\end{abstract}

Keywords-managerial competence, school principal, inclusive education

\section{INTRODUCTION}

Education is the most important thing in human life regardless of race, ethnicity, religion and physical condition. Indonesia also views that education is the right of all citizens as stated in the 1945 Constitution Article 31 paragraph 1 states that: "Every citizen has the right to education." Based on that, all citizens have the right to education without exception for children with special needs. The Banda Aceh government has appointed several schools to provide inclusive education. These schools play an important role in providing educational services by involving students with special needs to study with other students at the regular school closest to where they live. Schools that provide inclusive education must be able to protect all students according to their characteristics and needs. The aim of the government in designating regular schools to be inclusive school was in order that all students can get proper education in accordance with the students' conditions. Schools must be able to facilitate all students with special needs and other students in getting education.
This study aims at determining specifically the managerial competence of principals in the implementation of inclusive education. The role of the principal is very important in accordance with his function as a manager. The principal must be able to create a proper learning atmosphere for all students including students with special needs. One of the roles of the principal is to plan, formulate the vision and mission of the school, implement the curriculum, and prepare educators and education personnel, as well as infrastructure. Previous research has also suggested that school principals responsible in developing an inclusive vision, fostering educators and education personnel, students, parents of students with special needs, and the community [1].

In educational organizations such as schools, the management of school principals is a top priority. The principal himself is the top leader and is the most important part in the world of education where students gain knowledge. The success or failure of a school cannot be separated from the role of the principal. The principal as a manager has an important role as an education manager who has the responsibility of providing inclusive education with all of its substances [2].

The principal is a factor that can improve the quality of education through the ability as a manager in the school being led. This kind of competence is needed in regular schools that provide inclusive education. It is needed both from the aspect of school management which is the duty and responsibility of the principal as well as class management and learning which are the duties and responsibilities of the teacher. The principal as the manager can compile and implement policy planning as outlined in the formulation of the vision, mission and goals of the school by involving all school components and paying attention to the things needed to improve the quality of education.

There are three managerial skills that must be mastered by a principal as a manager, namely: a). Technical skills; the ability to use tools, procedures, specialist techniques, surgeons, technicians, musicians and accountants; b) Human skills that is the ability to work with others, understand others and encourage others both as individuals and groups; c) Conceptual skills, are mental abilities to coordinate and integrate all 
organizational activities [3]. Principals who are able to master these three managerial skills will easily direct the school to be better so that all goals will be achieved.

The principal as manager has a big role in the world of education and as a key to the progress of the school. The principal is expected to be able to build good relationships with subordinates in the school which will facilitate the achievement of planning. The principal plays an active role in providing all important information needed either to teachers, school stakeholders, parents of students or other parties. All decisions made by the principal must be done wisely, so that no one is harmed, either personally or for the sake of the school's sustainability. The decision of the principal is expected to make the school better and that all the goals set by the school community can be achieved.

In schools that provide inclusive education, the principal together with the teacher must adapt the curriculum to the national curriculum used in ordinary schools. The curriculum that is made must be tailored to the needs of students with special needs. There are five models of inclusive education curriculum which include: 1). The escalation model, namely the national standard curriculum that raises the material qualification level horizontally or vertically in accordance with the potential demands of smart / gifted students; 2). The duplication model, which is a curriculum development method for students with special needs that uses a national standard curriculum that applies to regular students. Duplication consists of copying purposes, materials, processes, and materials; 3 ). The modification model, namely the curriculum development method by changing the national standard curriculum that applies to regular students to suit the abilities of students with special needs, so that students with special needs undergo a curriculum that suits their abilities and needs. Modifications made consisted of adjusting objectives, materials, processes, and evaluation. 4). The substitution model is replacing national standard curriculum materials with other materials because the content of the national curriculum cannot be applied to students with special needs, but can still be replaced with other materials that are more or less in accordance with the learning objectives, materials, processes, or evaluations. 5). Negligence, model, In compiling curricula in schools that provide inclusive education, teachers can work together with special guidance teachers (GPK), resource centers or other experts. The curriculum model used for students with special needs must be tailored to the needs of these students.

Teachers cannot equate the application of a curriculum model for all students with special needs in an inclusive classroom. Teacher competence in curriculum management is very important in inclusive education, because teachers can adjust the regular school curriculum by sharing the ability levels of students including students with special needs [4]. Each has its own uniqueness. However, it is still possible for teachers to use the same curriculum model if after assessing them it turns out that students have the same needs as regular students in learning. The ability of the teacher to adjust the curriculum model that will be used by students with special needs depends on the results of the student's assessment and the competence of the teacher.

Several schools that provide inclusive education provide opportunities for students with special needs to be accompanied by shadow teachers. They will help those students to stay focused on learning, participate in class, be able to socialize with friends, and be independent in every activity in the classroom and school environment [5]. Shadow teachers are usually provided by parents of those students which are the result of an agreement between the school and the parents. The fee for this Shadow Teacher come from the parents themselves. The obstacles found in the implementation of inclusive education are that the existing curriculum does not accommodate students with special needs, inadequate assessment, and less supportive teacher factors [6].

\section{RESEARCH METHODS}

The approach used in this research is descriptive analysis method. It was conducted in several elementary schools in Banda Aceh. The schools are divided into two categories; core school and impact school. The instruments used in this study were interview guides, observation lists and notes. The validity of the study was assessed by the triangulation technique. The techniques used in this study were viewed from the data source, the techniques used and the time used. The triangulation technique in this study was carried out by comparing the interview data with observation and documentation.

\section{RESULTS AND DISCUSSION}

The results showed that the role of the principal as school manager was very important. The principal is at the forefront of improving the quality of education. The results of the study indicate several facts that the principal's managerial competence in providing inclusive education is needed.

\section{A. Planning in the Implemented Inclusive Education}

The school's vision, mission and goals are formulated by the principal, teachers, educational staff, school committees and school supervisors. Those that have been formulated are expected to be able to accommodate all students needs. Based on the results of observations and interviews, it was found that only a few schools had formulated the vision, mission and goals of the school which reflected being schools that provided inclusive education. However, the school environment is very conducive so it is very comfortable for all students including students with special needs.

The work plan and school budget prepared have included the needs of all students even though they are not specific to the needs of students with special needs. The commitment of all school members is very good so that services for students with special needs are in accordance with the goals to be achieved. All sample schools in this study have prepared a school work plan and a school budget work plan. The principal must have a strong belief in order to compile an inclusive education program that is beneficial for parents and teachers so 
that it affects the learning outcomes of students with special needs [7]. Schools designated to provide inclusive education must be ready from all aspects, most importantly teachers and infrastructure. This appointment is sometimes not followed by the readiness of the designated school. Government policies are very supportive of the implementation of inclusive education but teachers have not been given maximum training, the inadequate infrastructure in the designated schools make it difficult for persons with disabilities to access [8]. Based on this, the role of the principal as a manager is very important, so that these problems can be handled.

\section{B. The Students with Special Need}

The admission system for students with special needs is carried out in the same way as other normal students, namely by means of a zoning system that has been determined by the government. The principal has made a policy for students with special needs who do not have a certificate regarding the type of disability from a doctor or experts in their field, so that they can be brought to school for initial assessment by the committee for admitting new students. In accordance with technical guidelines from the Aceh government, students with special needs are accepted at most 3 people and are adjusted to the type of disturbance or obstacle they are experiencing.

Observations made by researchers prove that the school has accepted students with special needs. The acceptance is carried out in accordance with the provisions that have been determined. The school begins the admission of new students by identifying and assessing students with special needs with the aim of being able to provide services according to the conditions of students [9]. The identification and assessment carried out by the school aims to determine the types of disabilities experienced by students with special needs. This grouping is intended to determine the types of disabilities suffered in order to make it easier for schools, especially teachers, to serve students with special needs to get proper education. Each type of disability has different needs in learning, socializing, infrastructure, special media.

Teachers will find it easier to serve students with special needs if they have special supervisors (GPK). From the results of observations and interviews, only a few schools have special supervisors (GPK). The special guidance teacher available at the school is an initiative of the school principal by involving the teacher in every event to increase competence in serving students with special needs.

The principal managerial competence must be supported by optimal cooperation from the teachers. That's all because the teacher is a major component in the learning process in the classroom. Teacher training is needed to improve competence to serve students with special needs. Every country must issue a policy to conduct inclusive education training for teachers so that reliable resources are available so that the practice of inclusive education in the classroom runs effectively and efficiently [10]. Teacher competency development that focuses on inclusive education can be done by making educational programs that are equitable and valuable [11]. Some primary schools already have special supported teachers graduated from disability educational qualifications and primary school education teachers. Meanwhile, other schools do not have special guidance teachers so that students with special needs are only served by their homeroom teachers. The need for special guidance teachers is very important in terms of helping class teachers handle students with special needs such as compiling programs, conducting assessments, and class teacher constraints in serving students with special needs.

Some schools have shadow teachers. They are the ones who accompany students with special needs in order to follow the learning carried out by the teacher. The presence of shadow teachers is very helpful for teachers in serving students with special needs in the classroom. Each parent provides a diagnosis report from a specialist doctor or psychologist regarding the disability suffered by their child. However, those who do not have the results of the diagnosis will be assisted to obtain them through an assessment conducted by the school.

Parents of students whose children are assessed by the school state that the results of the diagnosis given will be discussed with the parents of students and then referred to the hospital, doctor or psychologist to get a more accurate diagnosis. It is all because schools do not have the authority to determine the type of disability experienced by students According to the testimony of these parents, their children who attend inclusive schools experience an increase in behavior change, especially in socializing with peers. Parents really appreciate school principals, teachers, and stakeholders who are willing to accept and provide special services to their children.

\section{Curriculum Management}

The curriculum used by inclusive schools is the same as the national curriculum used by other regular schools. A small number of schools modify the curriculum according to the needs of students with special needs. The school makes modifications, additions and removes in the learning process even though it has not been documented in the syllabus, annual program, semester program, and learning implementation plan.

The principal through supervision found that the teacher had taken a different approach to normal students and students with special needs in the learning process. The actual curriculum is in the teacher himself. so it can be said that the teacher himself is a living curriculum. No matter how good the existing curriculum and education system are if they are not supported by the ability of teachers, everything will be in vain. Teachers are competent and responsible, especially in guarding the maximum development of students [12].

\section{Motivation}

The motivation given by the principal to all school members causes the implementation of inclusive education in schools to be more effective. The principal always provides direction and guidance to all school members. Motivation is carried out by discussing with teachers who experience 
problems in providing educational services to special needs students. Based on the explanation given by the principal, it is known that the actions that have been taken when experiencing problems in dealing with students with special needs by finding solutions that involve teachers who have attended inclusive education training and also parents of students with special needs.

The principal must psychologically support the teacher in mastering pedagogic competencies in order to implement it in a classroom where there are students with special needs [13]. Support from the school principal motivates teachers to be able to provide the best service to students with special needs. The motivation given by the principal causes teachers to continue to learn and seek information from various sources about inclusive education. Thanks to the encouragement from the principal, all teachers accept the presence of students with special needs.

\section{E. Financing}

Based on the results of observations and interviews with school principals, the available funding for the implementation of inclusive education is not yet adequate. Not all the provision of infrastructure or special media needed by students with special needs can be budgeted for in the school budget. This is due to the unavailability of sufficient school funds to meet the provision of facilities and infrastructure that support the education of students with special needs. Limited funds have resulted in schools not being able to maximize services to students with special needs according to their needs. Training is urgently needed by teachers in inclusive schools which aim to improve the competence of these teachers in order to provide optimal services to students. Teachers who work in inclusive schools should have three abilities, namely: 1). Teachers have an attitude of appreciating diversity in students; 2). Teachers are able to identify students with special needs; 3). Teachers can master concepts and skills according to the needs of students with special needs [14].

During the COVID-19 pandemic only a few teachers attended online training. Whereas in the previous year, there were several schools that carried out inclusive training independently, where funding was budgeted in the school operational assistance fund (BOS). The Banda Aceh Education Office has also conducted training to improve teacher competence in implementing inclusive education based on applicable regulations.

\section{F. Principals, Teachers and Stakeholders' Roles}

Schools that provide inclusive education need school principals and teachers who understand the characteristics of students with special needs. Principals and teachers of students with special needs must understand the specific psychology of students. With the right principal and teachers, students with special needs will get the right education and teaching. However, there are still principals who do not fully understand inclusive education management, provide motivation to teachers, collaborate with students with special needs, and lack commitment in serving students with special needs in accordance with applicable regulations.

Almost some teachers do not understand how to serve students with special needs, knowledge about various types of disabilities, commitment with parents of special students is not optimal. There are parents of students with special needs hiding the condition of their children, parents do not care about their children. It turns out that the obstacles in the implementation of inclusive education are caused by internal and external factors. This internal factor is found in teachers who lack the ability to serve students with special needs and understand the characteristics of students with special needs. Apart from teachers, other obstacles are also found in school principals who are less committed to implementing inclusive education and the infrastructure that is still very minimal. While external factors involve parents of students with special needs, parents of regular students [15].

\section{G. Evaluation}

The principal conducts evaluation through direct and indirect supervision and observation. If there are still many obstacles from the results of the evaluation, the principal can change the way to implement inclusive education in the school that is led. The principal as a school administrator must make a direct approach to teachers by monitoring, guiding, and setting an example in implementing inclusive education [16]. From the findings, it is known that the principal made a policy to improve services for all students including students with special needs in order to get a proper education so that the quality of education will increase.

The teacher also does it for regular students and students with special needs. Evaluations are carried out differently, because the basic competencies achieved by students automatically vary. In addition, there are also schools that lower the Minimum Completeness Criteria Standard (KKM) that students with special needs must achieve.

The success of implementing inclusive education in these schools cannot be separated from the role of the school principal as manager. The principal as a person who has a very important role in this success must be able to carry out his duties as a manager. The principal must be able to increase the potential contained in his teacher in order to provide optimal services for students with special needs. One of them is by assigning them to attend training to improve teacher competence in dealing with students with special needs.

Based on the results of the interviews the researchers conducted with the school committee, it can be concluded that the implementation of inclusive education has gone well. The school committee and parents of other students do not mind accepting students with special needs in regular schools. The Banda Aceh Education Office considers inclusive education to be very necessary, so it plans to add several schools to become schools that provide inclusive education by 2021 . 


\section{CONCLUSION}

All schools have committed to implementing inclusive education. The role of the principal is the most important factor in the success of implementing inclusive education. Principals, teachers, and all stakeholders have provided the best services for students with special needs. Only a few schools have a vision, mission, and goals that reflect inclusive education schools. Has not received monitoring and evaluation in implementing inclusive education optimally. The supervision carried out so far is still internal by the school principal. The constraints faced by schools in implementing inclusive education are the unavailability of special guidance teachers who are professional and proportional to the number of students with special needs. The availability of infrastructure is also inadequate. There are schools that do not have special media for students with special needs.

\section{REFERENCES}

[1] C. Thompson, "The Principals' Impact on the Implementation of Inclusion," Journal of the American Academy of Special Education Professionals, vol. 136, pp. 141, 2015.

[2] E. Sulasmi, and A. Akrim, "Management construction of inclusion education in primary school,” Kumpulan Makalah, Jurnal Dosen, 2020.

[3] M. Kristiawan, D. Safitri and R. Lestari, Manajemen Pendidikan. Yogyakarta: Deepublish, 2017.

[4] I. Fedulova, V. Ivanova, O. Atyukova, and V. Nosov, "Inclusive education as a basis for sustainable development of society," Journal of social studies education research, vol. 10, pp. 118-135, 2019.

[5] N. Yunaini, "Model Pembelajaran Anak Berkebutuhan Khusus Dalam Setting Pendidikan Inklusi," Journal of Elementary School Education, vol. 1 , no. $1,2021$.
[6] A. Amka, "Pendidikan Inklusif Bagi Peserta didik Berkebutuhan Khusus di Kalimantan Selatan," Jurnal Pendidikan dan Kebudayaan, vol. 4, 2019.

[7] C. Lynch, Training and Experience as Predictors of Principals' Efficacy for Inclusive Education Implementation.

[8] I.K. Khan, S.H. Hashmi, and N. Khanum, "Inclusive education in government primary schools: Teacher perceptions," Journal of Education and Educational Development, vol. 4, pp. 32-47, 2017.

[9] N.D. Budiarti and S. Sugito, "Implementation of inclusive education of elementary schools: A case study in Karangmojo Sub-District, Gunungkidul Regency," Journal of Education and Learning, vol. 12, pp. 214-223, 2018.

[10] D. Supriyanto, "Teachers' attitudes towards inclusive education: A literature review," IJDS: Indonesian Journal Of Disability Studies, vol. 6, pp. 29-37, 2019.

[11] N. Muthukrishna, and P. Engelbrecht, "Decolonising inclusive education in lower income, Southern African educational contexts," South African Journal of Education, vol. 38, 2018.

[12] E.I. Yunita, "Manajemen Pendidikan Inklusi dalam Proses Pembelajaran dan Penanganan Guru Terhadap Anak Berkebutuhan Khusus," Jurnal Internasional Pendidikan Dasar, vol. 3, no. 3, pp. 267-274, 2019.

[13] Z. Ke, N.U. Borakova, and G.V. Valiullina, "Peculiarities of psychological competence formation of university teachers in inclusive educational environment," EURASIA Journal of Mathematics, Science and Technology Education, vol. 13, pp. 4701-4713, 2017.

[14] M. Yasdar, S. Djafar, E. Elihami, and F. Faisal, "Teaching Methods Used by Teachers in Primary Schools Inclusive," Edumaspul: Jurnal Pendidikan, vol. 4, pp. 108-114, 2020.

[15] D.D. Fajarwati, Implementation of School Management Inclusive Education Institutions. In 2nd International Conference on Educational Management and Administration (CoEMA 2017) (pp. 85-91). Atlantis Press, 2017.

[16] Y.P. Zapata, A principal's role in creating and sustaining an inclusive environment. San Diego: San Diego State University, 2015. 